http://kitaibelia.unideb.hu/

ISSN 2064-4507 (Online) • ISSN 1219-9672 (Print)

(C) Department of Botany, University of Debrecen, Hungary

26(2): 157-164.; 2021

DOI: $10.17542 /$ kit. 26.157

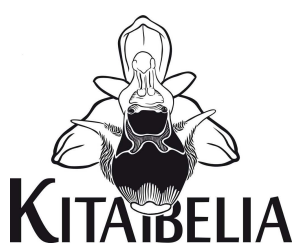

\title{
A Cyperus odoratus Magyarországon
}

\author{
MEsterházy Attila \\ Ökológiai Kutatóintézet, Vízi Ökológiai Intézet, Tisza Kutató Osztály, 4026 Debrecen, Bem tér 18/C; \\ amesterhazy@gmail.com
}

\section{Cyperus odoratus in Hungary}

\begin{abstract}
Eleven species of the genus Cyperus have been reported from Hungary so far, of which 3 are certainly aliens. A small population of $C$. odoratus, new for the flora of Hungary, was found along the River Danube near Foktő settlement (Bács-Kiskun County, S Hungary) in late autumn of 2019. On this occasion blooming specimens were observed in the floodplain ruderal vegetation on the bank of a fork of the Danube. This species is widespread in the tropical and subtropical regions of the World, and was first introduced to Europe in the early 1950s. More recently it has been spreading along certain rivers of Italy and Spain. It was discovered along the river Danube in Romania in the early 1990s, and later at the upper parts of the river in Bulgaria, Croatia and Serbia. Its introduction into Hungary is connected with the Danube, too. Based on foreign experience, it is probable that $C$. odoratus will be spreading along the Hungarian Danube system, hopefully, not as an invasive species.
\end{abstract}

Keywords: alien species, Cyperaceae, Hungarian flora, riverbanks, ruderal communities

Összefoglalás - Magyarország területéről eddig a Cyperus nemzetségnek 11 faja volt ismert, ezek közül biztosan 3 tekinthető adventívnek. 2019 őszén a szubtrópusi-trópusi elterjedésű $C$. odoratus kis állománya került elő a Duna alsó szakaszán, Foktő mellől. A faj virágzó példányai viszonylag késő ősszel bukkantak fel egy Duna-mellékág szárazra került szegélyében, kifejlődött, ártéri ruderális növényzetből. A Föld trópusi, szubtrópusi régióiban elterjedt faj már az 1950-es években megjelent Európában, és leginkább Olaszország és Spanyolország egyes folyói mentén terjedt el. A Duna mentén az 1990-es évek elején jelezték Romániából, később a folyam felsőbb szakaszán is elterjedt Bulgáriában, Horvátországban és Szerbiában. Hazánkba is valószínúleg a folyam közvetítésével jutott el. A külföldi tapasztalatok alapján várhatóan a hazai Duna szakaszon is stabilan meg fog telepedni, de remélhetőleg nem fog inváziós fajjá válni.

Kulcsszavak: adventív fajok, ártér, Cyperaceae, magyar flóra, ruderális élőhely

\section{Bevezetés}

A kozmopolita palka (Cyperus L) nemzetségbe a közelmúlt filogenetikai kutatások (LARRIDON et al. 2013). eredményeképp több, korábban önálló génuszt (pl. Kyllinga, Pycreus, Mariscus) is beolvasztottak. Ez alapján napjainkban a nemzetség mintegy 950 fajt foglal magába (GovAERTS et al. 2021), melyek a nagyfokú morfológiai hasonlóság miatt gyakran nehezen különíthetők el. A palkák nagyrészt a trópusokon elterjedtek, a mérsékelt égövben fajszámuk jóval alacsonyabb. Hazánkban a nemzetségnek mindösszesen 11 képviselője ismert. Közös jellemzőjük, hogy előfordulásuk döntően vizes élőhelyekhez kötődik. Ezek közül csak egy, a C. fuscus az, amely gyakorinak mondható, a másik 5 őshonos fajunk csak szórványos vagy ritka előfordulású (LÁJER 2009). A behurcoltak közül a C. difformis nálunk a rizstermesztéssel 
terjedt el (UBRIZSY 1948, 1961), de napjainkban már más élőhelyeken (pocsolyáknál, természetes alföldi mocsarakban) is megtalálható (MoLNÁr \& PFEIFFER 1999). Az 1990-es évek elején a trópusi-szubtrópusi területek veszélyes gyomjaként számontartott $C$. esculentus is megjelent Keszthely környékén (DANCZA 1994), azóta a faj az ország számos területén, főleg kapáskultúrákban okoz jelentős problémát (DANCZA 2012). A C. eragrostis Lam. alkalmi adventív, mely már 1915-ben megjelent Győrben (Polgár 1941), ahol a herbáriumi adatok tanúsága szerint egészen 1925-ig gyűjtötték. A növényt a közelmúltban Tatán (MATUS et al. 2019) és Pécsett (WIRTH et al. 2020) is megtalálták. A globális kereskedelem és utasforgalom megnövekedésével Európában az utóbbi évtizedekben számos adventív palkaféle megtelepedését regisztrálták, jelenleg a Cyperus nemzetség a mintegy 20 behurcolt és megtelepedett faja ismert a kontinensen (VERLOOVE 2014). Közülük több a környező országokban is jelen van, ezek magyarországi megjelenése várható volt.

\section{Anyag és módszer}

A közösségi jelentőségű ártéri ruderális vegetáció felmérését a Duna teljes hazai szakaszán 2017-2019 között végeztük el, a Cyperus odoratus e munka keretében került elő. A faj morfológiáját a szerző sztereomikroszkóppal vizsgálta. A növényről a termőhelyen készült fotók IPhone 7-es telefonkészülékkel készültek, míg a faj füzérkéjéről Canon Power Shot AS2100 IS kamerával. A faj azonosítása VerLoove (2014) munkája alapján történt.

A közleményben említett taxonok tudományos neveinek használata KIRÁLY (2009) határozókönyvét követi. A faj bizonyító példányai a BP herbáriumba kerültek.

\section{Eredmények}

Hazai előfordulás körülményei

2019.10.31-én Foktő közelében lévő Nagy-szigeten, a Duna egy mellékágának szegélyében (KEF: 9479.3, Koordináta: 47³0’474” É, 1906’ 462" K) a szerző egy hazai fajoktól küllemében eltérő Cyperus fajt talált, melyet a morfológiai paraméterek vizsgálata alapján $C$. odoratus-nak határozott (3. ábra).

A különösen száraz ősz miatt a mellékág teljesen kiszáradt, a meder oldalában a régóta szárazra került részeken ruderális elemekkel (Chenopodium rubrum, C. glaucum, Bidens frondosa, Persicaria dubia) kevert mocsári növényzet (Myosotis scorpioides, Rorippa amphbia) alakult ki. Ebben a viszonylag nagy borítást (70-90\%) elérő vegetációban a $C$. odoratus szálanként a meder mindkét oldalán szórványosan, kb. 100 m hosszan volt megtalálható. Érdekességként említhető, hogy a vegetációban nagyobb borításban jelen volt a szintén szubtrópusi-trópusi elterjedésü Eclipta prostrata, melyet hazánkból eddig csak kertészetekben előforduló szökevényként jeleztek (TAKÁCs et al. 2020). A fajt a Duna alsóbb szakaszán már megtalálták nyílt felszíneken vagy ártéri ruderáliákban (DIHORU \& SÂRBU 1998, JERIĈEvić \& JERIĈEVIĆ 2017, PERIĆ \& RILAK 2017, TzoneV 2007), de hasonló természetes élőhelyeken előfordulását hazánkban még nem dokumentálták. A szóban forgó Duna-mellékág környezete ugyan inváziós lágyszárú fajokkal terhelt (Aster lanceolatus, Solidago gigantea), de ma még döntően természetszerü füzligetekkel körülvett. Az emberi zavarás minimális, leginkább horgászok látogatják a vízpartot. A mellékágban kiépített horgászhelyek azonban nem találhatók. A talaj bolygatása vadak (vaddisznó, szarvas) által több helyen megfigyelhető volt, de a $C$. odoratus inkább a növényzettel jobban benőtt helyeket részesítette előnyben. A faj feltételezhetően a Duna közvetítésével került be hozzánk, valószínűleg a szerbiai állományokból. A foktőihez hasonló mellékágak a Duna gemenci és bédai szakaszán több helyen is megtalál- 
hatók, így a fajnak ezeken a területeken számos további potenciális élőhelye van. Megtalálását nehezíti azonban, hogy élőhelyei általában nehezen megközelíthetők, valamint csapadékos ősz esetén október végére általában a vízszint emelkedésével víz alá kerülnek. A faj felfedezésekor még virágzó állapotban volt, de az enyhe ősz miatt valószínűleg november elején képes volt magot érlelni. Viszont nyár végén, ősz elején csak vegetatív állapotban van, így megtalálása, felismerése ilyenkor nehéz. Az utóbbi évek enyhébb őszi időjárása miatt hazánkban is lehetővé vált a trópusi, szubtrópusi $C_{4}$-es fajok termésérése, így ezek vélhetően a jövőben önfenntartó állományokat tudnak majd képezni. Terjedésükben a folyók fontos szerepet játszanak, és a vízszint emelkedésével-süllyedésével járó „bolygatással” létrejövő ártéri ruderáliák vagy efemer iszaptársulások potenciális élőhelyet fognak jelenteni a $C$. odoratus-hoz hasonló, zavaráskedvelő fajoknak. Mindezeket figyelembe véve a - környező országokhoz hasonlóan - a C. odoratus nagy eséllyel meg fog honosodni Magyarországon. Aktuálisan a hazai ártéri ruderáliákban a Cyperus nemzetségből a C. glomeratus, C. michelianus és a C. fuscus ismert. Korábban a Duna és a Dráva mentén szintén ilyen élőhelytípusban élt nálunk a C. serotinus.

\section{Elterjedése}

A C. odoratus L. [syn.: Papyrus odorata (L.) Kunth, Diclidium odoratum (L.) Schrad. ex Nees, Torulinium odoratum (L.) S.S.Hooper] egy szubtrópusi-trópusi régióban elterjedt, gyakori faj. Leggyakoribb az amerikai kontinensen, ahol az Egyesült Államoktól délre, egészen Argentína déli részéig hatol. Afrikában Szenegáltól Angoláig szinte mindenütt előfordul, Kelet- és DélAfrikából azonban hiányzik. Madagaszkáron, Ausztrália és Óceánia nagy részén megtalálható. Délkelet-Ázsiában széles körben elterjedt, azonban nyugaton már csak szórvány előfordulásai ismertek Irakban és Iránban (GovAERTS et al. 2021).

Európában bizonyíthatóan elsőként Olaszországban, a Pó-síkságon bukkant fel, ahol 1958-ban Casalmaggiore település mellett találták. Ma már a térségben meghonosodott és elterjedt faj (VERLOOVE 2014). Második európai behurcolódása Romániához köthető, ahol a Duna-deltából jelezték először még az 1990-es évek elejéről (Roman 1992, CiocÂRLAN 1992, 1994, NEGREAN 2011; SîRBU\&OPREA 2011). Bár a közelmúltból innét további adatokat közöltek (ANASTASIU 2011), a fajt egyelőre nem tartják Romániában inváziósnak (ANASTASIU et al. 2008). Bulgáriában szintén a Duna mentén találták meg 2000-ben Belene és Novgrad közelében ( $C$. strigosus-ként). Később több adatot is közölnek a Duna bolgár szakaszáról és egyes mellékfolyóiról (TzoNEv et al. 2003), melyek alapján úgy tűnik, az országban a növény meghonosodott. Szerbiában a Duna mellett lévő Mali Lap mocsárból, Dubovac mellől közölték a fajt szintén C. strigosus-ként (STEVANović et al. 2004,2005). Bár itt sem tartják inváziósnak, a közelmúltban Kovin és Mihajlovac közötti Duna-szakaszon számos nagyobb állománya alakult ki (VERLOOVE 2014). A C. odoratus harmadik európai megtelepedési gócpontja Spanyolországban van, ahol az Ebro folyó mentén 2006-ban már jelentős állományokat találtak (CASTROVIEjo 2006). A faj behurcolása tehát itt már jóval korábban megtörténhetett.

A szaporodó európai adatok alapján úgy tûnik, a kontinens déli részén a növény stabilan megtelepedett, bár invázióssá eddig sehol sem vált. Első felbukkanásai minden estben a folyók mentén történtek, és a faj később sem jutott messze a vízfolyásoktól.

A C. odoratus európai terjedésének nyomon követése nehézkes, ugyanis azt gyakran keverték a szintén behurcolt $C$. strigosus-szal, és így az egyes adatok hitelességének megállapítása legtöbb esetben csak a herbáriumi példányok vizsgálatával lehetséges (VERLOovE 2014). 


\section{Morfológiai jellemzése}

Egyéves vagy rövid életű, évelő növény, szára 15-200 cm magas, háromélü, alapjánál lilás színű. Levéllemezei laposak, 30-80 cm hosszúak, 1,5-2 cm szélesek. A virágzat elsődleges murvalevelei $2 \mathrm{~cm}$ szélesek, levélszerűek. Az összetett füzérek ecsetvirágzatot (anthela) alkotnak, amely mintegy $30 \mathrm{~cm}$ átmérőjü. A füzér 2-5 cm hosszú és 20-25 2,5 mm hosszú füzérkét foglal magába. A füzérkék világosbarnák vagy sárgásak, szétállóak. A pelyva $\pm 4 \mathrm{~mm}$ hosszú, kopasz, középere zöld, csúcsa hegyes. A füzérke tengelye ízekre tagolódik, melyek visszahajló szárnyai körülveszik a termés alapi részét, éréskor a pelyvák tövénél széttöredezik (1. ábra). Ez a jelenség egyedülálló a Cyperus nemzetségben. Porzó 2(-3). A bibe 3 ágú. Termése 1,8-1,9 × 0,5-0,6 mm, elliptikus, háromélü, sötétszürke vagy fekete, pontozott.

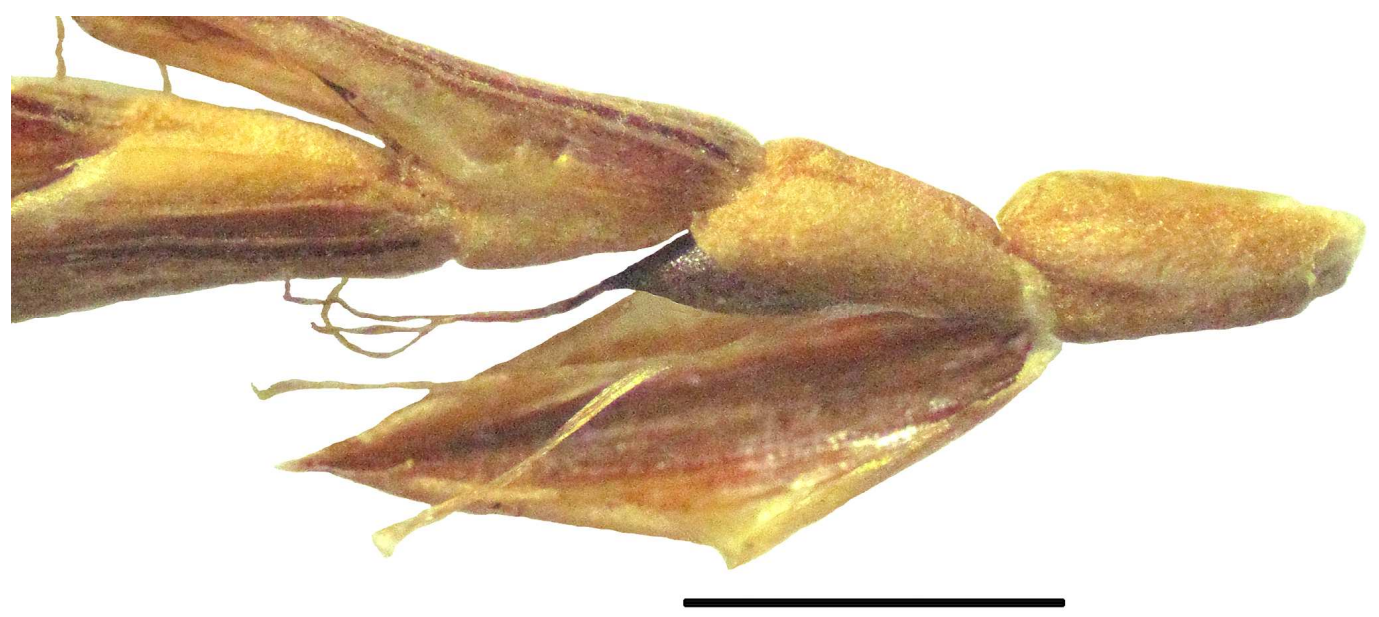

1. ábra A Cyperus odoratus füzérkének tengelye megvastagodott, a termést körülveszi. Éréskor a pelyvák tövénél széttöredezik (méretarány: $1 \mathrm{~mm}$ ) (Jane Browning felvétele)

Fig. 1 Rachilla of Cyperus odoratus is thickened and encloses the nutlet. At maturity rachilla is corky at the base of glumes and disarticulate in several units (scale bar $1 \mathrm{~mm}$ ) (photo by Jane Browning)
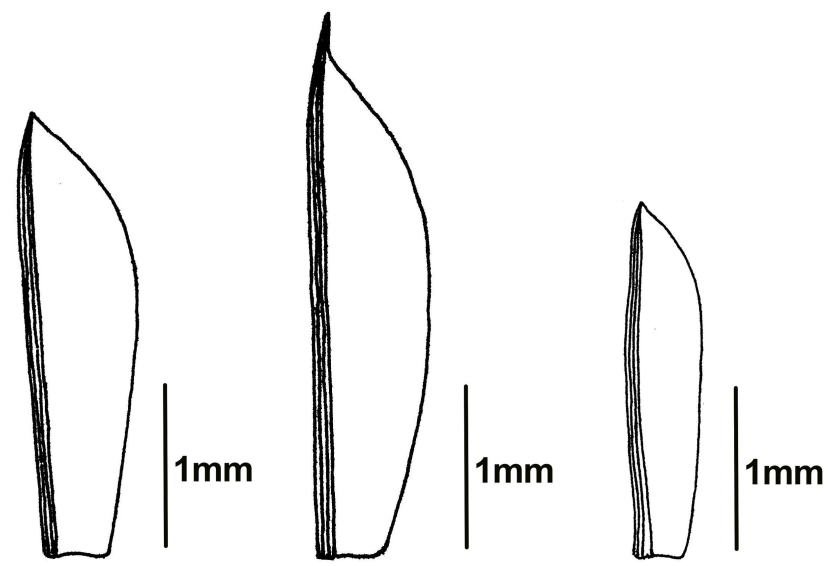

2. ábra A C. odoratus, a C. strigosus és a C. glomeratus pelyvái (Jana Táborska rajza) Fig. 2 Glumes of $C$. odoratus, C. strigosus and C. glomeratus (illustrated by Jana Táborska) 


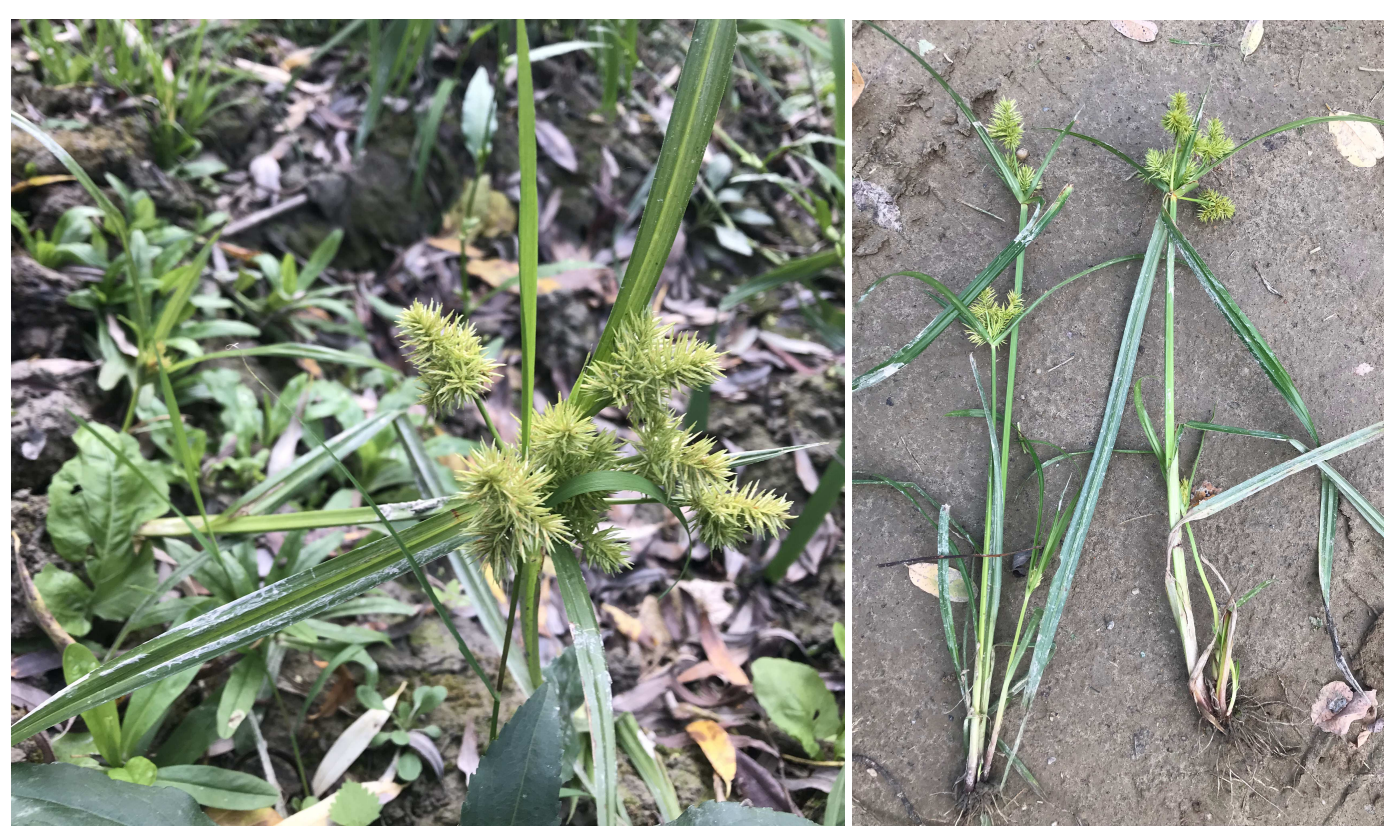

3. ábra $C$. odoratus habitusfotói a hazai termőhelyén (Mesterházy Attila felvételei)

Fig. 3 Habit of $C$. odoratus in the Hungarian locality (photographed by Attila Mesterházy)

A fajt gyakran tévesztik a $S$. strigosus-szal, melynek füzérjei teljes egészében esnek le éréskor, míg füzérkéi laposak, sárgászöldek. Pelyvája apró, szálkahegyű. Hasonló élőhelyeken fordul elő a hazánkban őshonos C. glomeratus is, mely az utóbbi években folyóink mellett jelentős terjedést mutat (Mesterházy ined.). Ennek a fajnak azonban a $C$. odoratus-nál tömöttebb füzérkéi vannak, pelyvái sokkal keskenyebbek. A három faj pelyvái közötti különbségeket a 2. ábrán mutatjuk be. Mivel a $C$. odoratus hosszú távon stabilan meg fog telepedni Magyarországon, így indokolt szerepeltetése a hazai Cyperus kulcsban (LÁjER 2009), ahová jelen munkában a korábban kimaradt, hazai előfordulással rendelkező fajok ( $C$. eragrostis és $C$. serotinus) is beillesztésre kerültek.

\section{Cyperus L. - Palka \\ [incl. Dichostylis P. Beauv., Chlorocyperus Rikli, Acorellus Palla, Juncellus C.B.Cl, Pycreus P. Beauv. Torulinium Desv.]}

1a A pelyvák a füzérkében három sorban, spirálisan állnak; fehéresek, zöldes, ormósan kiemelkedő középsávval. A levél 1-2 mm széles. Murváskodó levél 3-5(-8). A virágzat tömött fejecskeszerű, 6-12 mm Ø. A füzérke lándzsás, lapított, 2-4 mm hosszú, 8-16(20) virágú, tengelye keskenyen szárnyas. Porzó (1-)2(-3), bibe 2(-3). T: 2-15(-20) cm. Th. VII-IX. Homokos és iszapos partok, medrek, törpekákás társulások. DDt, NyDt ritka, KisA, A szórv. [D. micheliana (L.) Nees]

C. michelianus L. - Iszap p.

1b A pelyvák a füzérkében, 2 szabályos sorban helyezkednek el, a levéllemez lapos............. 2

2a A virágzat látszólag oldalsó állású, mert az alsó murváskodó levél a szár folytatásának látszik. - A szár felálló v. felemelkedő, legfeljebb $1 \mathrm{~mm} \emptyset$. A virágzat fejecskeszerü, (2)3-8(-10) ülő füzérkéből áll. A füzérke 5-8(-15) mm hosszú, 10-20(-40) virágú. A pelyvák széles-tojásdadok, vörösesbarnák, széles, halványzöld középsávval. Porzó 3, bibe 2. T: (1-)4-15(-30) cm. He(-Th). VII-IX. Kiszáradó, gyakran sótartalmú medrek, iszapos partok. DK (Balaton-fv.), DDt (Balaton-part), A (főleg Ttúl) ritka. [Acorellus pannonicus (Jacq.) Palla]

C. pannonicus Jacq. - Magyar p. 
2b A virágzat jól láthatóan végálló, a murváskodó levelek szétállók, nem látszanak a szár folytatásának

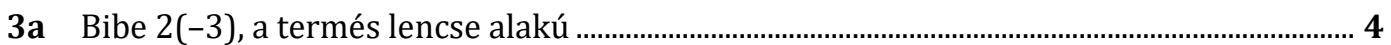

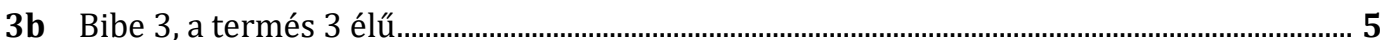

4a Egyéves, alacsony termetű növény, tömött sárga fejecskeszerű virágzattal, mely 2-4 nyeles részvirágzatból áll. A füzérke lándzsás, 5-12(-15) mm hosszú, oldalról erősen lapított, 5-25 virágú. A pelyvák szalmasárgák, zöld középsávval. T: $(1-) 5-30(-50) \mathrm{cm}$. Th. VII-IX(-X). Partok, kiszáradó árkok és tavacskák, csupasz, nedves felszínek, törpekákás társulások. Nagyon visszaszorult, ma M.e.t. ritka. [Pycreus flavescens (L.) P. Beauv. ex Rchb.]

C. flavescens L. - Sárga p.

4b Évelő, kúszó gyöktörzsű, erőteljes növény. A füzérkék vörösesbarnák, több cm hosszú ágakon füzéresen elállók. A füzérke elliptikus v. ovális 8-25 mm hosszú, oldalról gyengén lapított. A pelyvák vörösesbarnák v. sötétbarnák, zöld középsávval. T: 35-100 cm. Ge. (VII)-VIII-IX(-X). Folyó menti mocsarak, holtágak. Nálunk †, egykor A (Dráva-v.: Szaporca, Duna-v: Soroksár), DK (Keszthely?). [Duvaljouvea serotina, Juncellus serotinus (Rottb.) C.B.Cl.]

C. serotinus Rottb. - Őszi p. A szomszédos déli országokban terjedőben. Újbóli megtelepedése várható.

5a A füzérke tengelye ízekre tagolódik, melyek visszahajló szárnyai körülveszik a termés alapi részét. Éréskor a pelyvák eredésénél megtörik és a terméssel együtt darabokban hullik le. A levelek W keresztmetszetűek, 5-30(-60) cm × 4-12 mm-ek. A virágzat széles, elérheti a $30 \mathrm{~cm}$-t, a részvirágok lazábban álló henger alakú füzérkékből 2-5 cm átmérőjű fejecskékbe állnak össze. Pelyvák sárgák v. világosbarnák, 4 mm hosszúak, csúcsuk hegyes. Porzó 2-3. T: 15-200 cm. He(-Th). IX-X. Adv. (trópusi-szubtrópusi). Ártéri ruderáliák. A (Duna-v.: Foktő). Terjedőben. [Torulinium odoratum (L.) S.S.Hooper]

C. odoratus L. - Törékeny p.

5b A füzérke tengelye nem megvastagodó, a terméseket nem öleli körül. Éréskor a pelyvák leválnak az egészben maradó füzérke tengelyéről.

6a A füzérke tengelye nem szárnyas. A pelyva 0,5-1,3 mm hosszú............................................... 7

6b A füzérke tengelye a lefutó pelyvaszélektől szárnyas. A pelyva legalább 1,5 mm hosszú. 8

7a A pelyva 1-1,3 mm hosszú. A termés fehér. - A levél (1-)2-5 mm széles. Murváskodó levél 2-4(-8), az alsók sokkal hosszabbak a virágzatnál. A virágzat 2-5(-7) cm széles, a részvirágzatok fejecskeszerűek, 2-3 $\mathrm{cm}$ hosszú nyeleken ülnek. A füzérkék hosszúkásak, lapítottak, 3-8(-12) mm hosszúak. A pelyvák vöröses- v. feketésbarnák, zöld középsávval. Porzó 2. T: (2-)3-20(-40) cm. Th. VII-X. Törpekákás iszaptársulások, mocsári gyomnövényzet. M.e.t. gyakori.

C. fuscus L. - Barna p.

7b A pelyva 0,5-0,7 mm hosszú. A termés halványsárga v. sárgászöld. - A levél 2-4(-7) mm széles. Murváskodó levél 2-4, az alsó többszörösen hosszabb a virágzatnál. A virágzat gömbölyű fejecskékből tevődik össze, amelyekben sűrűn állnak a nyeles füzérkék (az elsőrendű sugarak hossza elérheti az $5 \mathrm{~cm}-\mathrm{t})$. A füzérke szálas, (2-)5-8(-10) mm hosszú. A pelyvák vörösesbarnák, zöldes középsávval. Porzó 1(-3). T: 20-50(-75) cm. Th. IX-X. Adv. (szubtrópusi-trópusi). Belvizes szántók, rizsföldek gyomnövényzete. DDt (BelsőSomogy) igen ritka, A szórv.

8a A füzérkék tömött, fejecskeszerú részvirágzatokba tömörülnek ………………………….... 9

8b A füzérkék nem fejecskeszerű részvirágzatokban, t-k. lazán helyezkednek el................... 11

9a Az érett füzérkék zöldesek vagy sárgásbarnák, porzó 1. Évelő, rövid gyöktörzsű növény. A levél 4-10 mm széles. Kúszó gyöktörzsű növény. A levél (2-)3-8(-10) mm széles. Murváskodó levél 4-8, az alsók jóval túlnyúlnak a virágzaton. A virágzat 3-10 sugarú, 2-6(-8) fejecskeszerű részvirágzatból áll. A füzérke 5-20 mm hosszú, lapított. A pely- 
vák 2-3 mm hosszúak. T: (10-)30-50(-70) cm. He-HH. (VII-)VIII-X. Ritka adv. (DAm.). Bolygatott, nedves helyek, mocsári gyomnövényzet. DDt (Pécs), KisA (Tata, Győr†). [Cyperus declineatus Moench] C. eragrostis Lam. - Fakó p.

9b Az érett füzérkék rozsdabarnák v. sötétbarnák, porzó 2 v. 3.............................................. 10

10a A pelyva szálas v. szálas-lándzsás, $0,5 \mathrm{~mm}$ széles. - Kúszó gyöktörzsű növény. A levél (2-)3-8(-10) mm széles. Murváskodó levél 3-6, az alsók jóval túlnyúlnak a virágzaton. A virágzat 3-10 sugarú, 2-6(-8) fejecskeszerű részvirágzatból áll. A füzérke 8-12 mm hosszú. A pelyvák rozsdabarnák v. vörösesek, zöld középsávval. Porzó és bibe 3-3. T: (10-)30-50(-70) cm. He-HH. (VI-)VII-X. Folyózátonyok, mocsári gyomnövényzet, iszaptársulások. DDt (Belső-Somogy, Dráva-m.), NyDt (Mura-v.) ritka, KisA, A szórv. Terjedőben. [Chlorocyperus. glomeratus (L.) Palla] C. glomeratus L. - Csomós p.

10b A pelyva elliptikus v. tojásdad, kb. 1,5 mm széles. - A levél 2-6 mm széles. Murváskodó levél 2-5, legalább az alsók hosszabbak a virágzatnál. A virágzat 4-8, a részvirágzatok tömött fejecskeszerűek. A füzérke 6-15 mm hosszú. A pelyva vörösesbarna, széles, zöldes középsávval és keskeny, hártyás szegéllyel. Porzó 2(-3), bibe 3. T: (8-)10-50 cm. Th. VIII-IX. Iszapnövényzet. DK (Velencei-hg.), DDt (Belső-Somogy), A (Mezőföld), igen ritka. [Chlorocyperus. glaber (L.) Palla] C. glaber L. - Kopasz p.

11a A pelyva homorú, halványsárga v. sárgásbarna, feltűnően kiemelkedő erekkel. A gyöktörzsön gumók fejlődhetnek. - A gumó 1-2 cm Ø. A levél 2-10 mm széles. A virágzat 410 sugarú, a sugarak hossza elérheti a $10 \mathrm{~cm}$-t. A füzérke szálas v. keskeny-hosszúkás, 5-16(-20) mm hosszú. T: 5-60(-90) cm. Ge(-Th). (VI-)VIII-X. Adv. (szubtrópusi). NyDt (Zalai-dv.: Keszthely), DDt (Külső- és Belső-Somogy) A (D-T). Terjedő, veszedelmes szántóföldi gyom. C. esculentus L. - Mandula p. A var. sativus Boeck. termesztett olajnövény, a gumó 1-2 cm Ø, ritkán virágzik. A (nálunk terjedő) var. leptostachyus Boeck. gumója legfeljebb $1 \mathrm{~cm} \emptyset$.

11b A pelyva ormós hátú, barna v. vörösesbarna, csak kevéssé kiemelkedő, gyenge erekkel. A gyöktörzsön nincsenek gumók. - Élénkzöld növény, erős, hosszan kúszó gyöktörzzsel. A levél (2-)4-7(-10) mm széles, lapos, merev. A virágzat 6-10 sugarú, ezek $35 \mathrm{~cm}$ hoszszúak is lehetnek. A füzérkék 3-12-es csoportokban helyezkednek el, (5-)10-25 mm hosszúak. T: (20-)40-90(-150) cm. Ge-HH. V-VIII(-X). Magassásosok, nádasok, nedves rétek. DK (Szigliget), DDt (Balatonmáriafürdő, Pécs, Máriagyűd), KisA (Tata), A (Dunav.: Baja k., egykor Tt?), eltűnőben. [Chlorocyperus. longus (L.) Palla]

C. longus L. - Hosszú p.

\section{Köszönetnyilvánítás}

A terepi munkát KEHOP-4.3.0-VEKOP-15-2016-00001. projekt Natura-fejlesztési elemének, A közösségi jelentőségû fajok és élőhelyek megőrzését szolgáló tudásbázis fejlesztése című program keretében végeztük. A faj illusztrációinak elkészítéséért Jana Táborska-t és Jane Browning-ot illeti köszönet.

\section{Irodalom}

AnAstasiu P. (2011): New taxa and chorological data for Danube delta flora. - Acta Horti Botanici Bucurestiensis 38: 33-38.

Anastasiu P., Negrean G., Bașnou C., Sîrbu C. \& Oprea A. (2008): A preliminary study on the neophytes of wetlands in Romania. In: RABITSCH W., EssL F. \& KLINGENSTEIN F. (eds), Biological Invasions - from Ecology to Conservation. - Neobiota 7: 180-190.

Castroviejo S. (2006): Más sobre Cyperus y Kylinga en la Península ibérica. - Acta Botanica Malacitana 31: $232-238$. 
CioĈARlAn V. (1992): Additions to the flora of Romania. - Studii si Cercetari de Biologie Seria Biologie Vegetala 44: 109-113.

CioĉARlan V. (1994): Flora Deltei Dunării. - Ceres, București, 115 pp.

DANCZA I. (1994): A mandulapalka (Cyperus esculentus L.) előfordulása Keszthely-Hévíz határában. Növényvédelem 30(10): 475-476.

DANCZA I (2012): Mandulapalka. - In: CsISZÁR Á (szerk.), Inváziós növényfajok Magyarországon. Nyugatmagyarországi Egyetem Kiadó, Sopron, pp. 325-330.

DiHoRU G. \& SÂRBU A. (1998): Eclipta prostrata (fam. Asteraceae), neofita in flora Romaniei. - Acta Horti Botanici Bucurestiensis 1996-1997: 95-99.

Govaerts R., Jimenez-Mejias P., Koopman K., Simpson D., Goetghebeur P., Wilson K., Egorova T. \& Bruhl J. (2021): World Checklist of Cyperaceae. - Facilitated by the Royal Botanic Gardens, Kew. Published on the Internet: http://wcsp.science.kew.org/ (Hozzáférés: 2021. 01. 22.)

JeRIĈEVIĆ M. \& JERIĈEviĆ N. (2017): Eclipta prostrata (L.) L. a new alien species in Croatian flora. - Natura Croatica 26: 105-109.

KIRÁLY G. (szerk.) (2009): Új magyar füvészkönyv. Magyarország hajtásos növényei. Határozókulcsok. ANP Igazgatóság, Jósvafő, 616 pp.

LÁJER K. (2009): Cyperaceae L. - In: KIRÁLY G. (szerk.) (2009), Új magyar füvészkönyv. Magyarország hajtásos növényei. Határozókulcsok. ANP Igazgatóság, Jósvafő, pp. 545-570.

Matus G., Aszalós R., Dorotovič Cs., Hanyiska M., Hüvös-RÉcsi A., Musicz L., Miglécz T., PApp M., Schmotzer A., TöröK P., VAlKó O., VojtKó A., HARTMAnn J., TAKÁcs A. \& BAlogh R. (2019): Kiegészítések a magyar flóra ismeretéhez. - Botanikai Közlemények 106(1): 71-112.

Molnár V. A. \& Pfeiffer N. (1999): Adatok hazai Nanocyperion fajok ismeretéhez II. Iszapnövényzet kutatás az ár- és belvizek évében Magyarországon. - Kitaibelia 4(2): 391-421.

NEgREAN G. (2011): Addenda to "Flora Romaniae" volumes 1-12. Newly published plants, nomenclature, taxonomy, chorology and commentaries (Part 1). - Kanitzia 18: 89-194.

PERIĆ R. \& RilaK S. (2017): Eclipta prostrata (L.) L. (Compositae), an adventive species new to the flora of Serbia. - Botanica Serbica 41: 89-94.

PoLGÁR S. (1941): Győrmegye flórája. Flora Comitatus Jaurinensis. - Botanikai Közlemények 38: 201-352.

Roman N. (1992): Contribuţii la cunoaşterea florei Rezervaţiei Biosferei Delta Dunării. - Analele ştiinţifice ale Institutului Delta Dunării, Tulcea, pp. 51-56.

Sîrbu C. \& OPREA A. (2011): Plante adventive în flora României. - Editura « Ion Ionescu de la Brad », Iaşi, $733 \mathrm{pp}$.

Stevanović V., ŠinŽAR-SEKulić J. \& Stevanović B. (2004): Expansion of the adventive species Paspalum paspaloides (Michx.) Schribner, Echinochloa oryzoides (Ard.) Fritsch and Cyperus strigosus L. in the Yugoslav part of the Danube reservoir (km 1090-1075). - International Association for Danube Research 35: 399-405.

Stevanović V., TAN K., TomašEvić M. \& Uotila P. (2005): The occurrence of Cyperus strigosus (Cyperaceae) in Serbia and Montenegro. - Phytologia Balcanica 11:137-138.

TAKÁCS A., Wirth T., SChMotZer A., Gulyás G., JoRdÁN S., SÜVEGES K., ViróK V. \& Somlyay L. (2020): Cardamine occulta Hornem. Magyarországon, és a dísznövénykereskedelem más potyautasai. - Kitaibelia 25(2): 195-214.

Tzonev R. (2007): Eclipta prostrata (Asteraceae): a new alien species for the Bulgarian flora. Phytologia Balcanica 13: 79-80.

TZonEv R., ZielińSKI J. \& TAN K. (2003): Cyperus strigosus (Cyperaceae), a naturalized species new to Bulgaria. - Polish Botanical Journal 48: 47-49.

UBRIZSY G. (1948): A rizs hazai gyomnövényzete. - Acta Agrobotanica Hungarica 1: 1-43.

UBRIZSY G. (1961): A magyarországi rizskultúrák gyomvegetációja. - Acta Botanica Hungarica 7: 175-220.

Verloove F. (2014): A conspectus of Cyperus s.l. (Cyperaceae) in Europe (incl. Azores, Madeira and Canary Islands), with emphasis on non-native naturalized species. - Webbia 69(2): 179-223.

WiRTH T., KovÁCS D. \& CsiKY J (2020): Adatok és kiegészítések a magyarországi adventív flóra kivadult, meghonosodott és potenciális inváziós fajainak ismeretéhez. - Kitaibelia 25(2): 111-156.

Beérkezett / received: 2021. 05. 25. • Elfogadva / accepted: 2021. 06. 28. 